\title{
The difficulty in evidencing family estrangement to attain statutory finance in UK higher education.
}

\author{
Dr Becca Bland, Stand Alone Charity. \\ Dr Lucy Blake, Edge Hill University, Faculty of Health \\ and Social Care.
}

\begin{abstract}
Acquiring statutory funding to study in higher education (HE) brings complex difficulties for UK students under the age of 25 who are estranged from their family, but have not been part of the care system. This paper explores the experiences of 564 estranged students and their experiences of providing evidence of family estrangement in order to access statutory student financial support. It finds that those who disclosed their family estrangement to a professional found it easier to access statutory student finance. However, the stigma around family estrangement was a barrier to disclosure as participants felt shame and humiliation when approaching a professional to support their application. These difficulties led to substantial delays in receiving statutory finance for estranged students which subsequently had an impact on their retention and equitable student experience at the beginning of the academic year. The paper concludes with key recommendations for improvements to the process of proving family estrangement. It will question the parental 'meanstesting' system itself, outlining key disadvantages for students experiencing family disruption.
\end{abstract}

Adquirir una fuente de ayuda financiera para optar a estudios superiores acarrea dificultades complejas para los estudiantes británicos menores de 25 que no mantienen ninguna relación con su familia, pero que tampoco han formado parte de los mecanismos del sistema de asistencia. Este documento explora las experiencias de 564 estudiantes que no mantienen ninguna relación con sus familias y de sus experiencias a la hora de aportar evidencias de tal situación de cara a acceder a las ayudas económicas. Se evidencia que aquellos que revelaron la ruptura de las relaciones con sus familiares a un profesional tuvieron un acceso más fácil a las ayudas de financiación para los estudios. Sin embargo, el estigma que aún hoy en día rodea a dicho distanciamiento de la familia supuso una barrera para su revelación. Estas dificultades condujeron a retrasos sustanciales para recibir los fondos para los estudiantes, lo que a su vez tuvo un impacto en su retención y su experiencia igualitaria al principio del anos académicos. El documento concluye con recomendaciones clave para realizar mejoras de ayuda financiera por los estudiantes que no mantienen ninguna relación con sus familias. 


\section{Keywords: Family Estrangement, Estranged Students, Student Finance, Stigma, Persistence, Higher Education, Student Success.}

\section{Introduction: Means-Testing and Dependent and Independent Students}

The student finance process across the four nations of the UK is built around a 'means-testing' system, whereby the household income of a student's biological parent(s) is assessed. If the parental household shows a household income of above the upper threshold, the household is expected to provide a level of financial support to the student, yet an exact figure is not provided to the parent (Lewis, 2019). If a parental household income is assessed below the lower threshold, a student will be provided with full state support and the parental household is not explicitly expected to contribute to the student's maintenance costs. Student Loans Company Ltd handles the 'means-testing' process in England, Wales and Northern Ireland and maintenance support is calculated on costs for up to 45 weeks of the academic year (SLC, 2019). Although means-testing exists across all four nations of the UK when awarding statutory student support, national governments in England, Wales, Scotland and Northern Ireland set differing policies around income and support thresholds. This means provision for students in the four nations, and the amount of debt they will take on, is variable. It reflects the differing Governments' attitudes towards higher education, widening participation and spending.

However, family support is assumed for young people as they enter higher education. The means-testing system in all four nations of the UK dictates that all students aged 18-25 are dependent on their parental household, unless they can provide evidence to the contrary. If a young person cannot provide either their parents household income details, or prove that they are an 'independent' student, they are awarded the lowest available amount of finance. However, if they are able to prove themselves to be independent of their parental household, they will be entitled to the maximum amount of finance, which is higher in consideration of the absence of the familial capacity to support the student (Ellet, 2017; Gov.uk, 2017; National Union of Students, 2008).

The Student Loans Company Ltd system does acknowledge that some students are independent of their family, and not all young people in higher education have access to parental support (Bland \& Shaw, 2015). This is true of care leavers, who may have been removed from their biological family and cannot be dependent on them (Jackson, 2006). Estranged 
young people have no contact with their parental household, and may come from similar family backgrounds to those who were taken into local authority care (Simon, 2008) yet have received little formal recognition or support with their family struggles from statutory sources (Bland \& Shaw, 2015, Bland, 2018). These young people, who are the focus of this paper, are known as estranged students (OfS (Office for Students), 2019).

Factors that contribute to family estrangement are diverse, and include feeling a lack of support, acceptance and/or love; abuse; a family member choosing one relationship over another; and having different values from one another (Blake, 2017). Furthermore, family estrangement may be common in communities that are more marginalized and stigmatized, such as Lesbian, Gay, Bisexual and Transgender (LGBT+) communities (Blake, 2017).

University life can be a struggle for estranged young people (Taylor, 2019; Bland, 2018). They often stretch their statutory finance to support themselves outside of term-time, due to a lack of parental financial or material contributions over the summer months. This has placed them into poverty, and inhibited academic focus, with a negative impact on student persistence (Bland, 2018). It also has an impact for estranged students on the ability to choose accommodation with peers and live as part of the institutional community (Bland, 2018). Despite the clear struggles of institutional life as an independent student, it remains imperative for estranged students to qualify as independent from their parental household. Such students need the maximum financial means to meet rising maintenance costs and minimise barriers to student success.

This paper will explore key issues that estranged students face in terms of proving their family estrangement and subsequently qualifying as an independent student in order to access maximum statutory finance. It will explore the impact of this process on their integration and aspirations to persist in higher education. In doing so, it will build on the sparse literature around estranged students and what is known of the scope of disadvantage that estranged young people may face when interacting with statutory support services. Furthermore, this paper will build on the literature in the field of family estrangement, which has not discussed young adults or the student population extensively.

\section{Literature Review}




\section{Family Estrangement}

The literature around estrangement from family suggests it can be a healthy response to an unhealthy family situation (Agllias, 2011; Scharp, \& McLaren, 2017) or a move to ensure safety and 'survival' from violence and abuse in the family (Agllias, 2013). Abuse, clashes of personality and values and mismatched expectations around family roles and relationships have been identified as common factors that contribute to relationship breakdown with parents, siblings and children (Blake, 2015). Other factors include feeling a lack of support, acceptance and/or love; a family member choosing one relationship over another (Blake, 2017). Family estrangement has also been identified as being common in communities that are more marginalized, such as Lesbian, Gay, Bisexual and Transgender (LGBT+) communities (Blake, 2017). Research in the homelessness community who have estranged family relationships, suggests that such young people have experienced family support, or the withdrawal of support, on condition of their gender or sexuality being in line with their parent's expectations. More generally, this study suggested that family instability "drastically upset people's lives, including children and youth" (Robinson, 2018, p.385)

Stigma is common in relation to family estrangement, with many experiencing feelings of shame and embarrassment, as well as feelings of abnormality (Agllias, 2013; Scharp, Thomas, \& Paxman, 2015). More specifically, adult children who are estranged from their parents or family feel compelled to keep this information private, and when they have disclosed their situation to social networks, they feel unsupported (Agllias, 2017; Scharp, 2016) . Although the consequences of family estrangement have been explored to an extent, existing research has seldom discussed the impact of family estrangement on young adults aged under the age of 25 specifically.

\section{Estranged Young People In Higher Education}

The definition of family estrangement is the subject of debate within the estrangement literature (Blake, 2017). For clarity, this paper uses the policy definition, used by the Department for Education (DfE) and Student Loans Company Ltd. This definition states that a for a student to be considered estranged, they must have ceased communicative contact with their living biological or adoptive parents, normally for a period of twelve months prior to the start of their course, and the estrangement must be irreconcilable (Office For Students, 2019). 
The accommodation struggles of estranged young people entering higher education has been explored. A lack of finance drives estranged students into housing choices apart from their peers and the institutional community (Bland, 2018). The same study shows a percentage of estranged students have backgrounds of homelessness, either formal or informal. Students in this situation experience severe financial difficulties over the summer period whilst trying to find suitable and affordable accommodation without the material and financial support of a parent. Local authorities were little help to estranged young people pre-entry, who did not recognise their situation, or give them priority for accommodation support (Bland 2018). This study and Simon's 2008 study on 'young people in difficulty' showed peer groups to be the main source of support for estranged young people.

Research with Scottish students suggests that proving family estrangement is challenging for young people in Scottish HE (Taylor, 2019). Recent investigative reports show that estranged students have experienced state-sanctioned surveillance of their social media platforms to monitor communicative contact with parents or family members (Wheel, 2018). This has resulted in the removal of statutory finance and psychological difficulties for those involved (Bland, 2018).

An older study by the National Union of Students (Malcolm, 2008) documents the difficulties that 30 LGBT+ estranged students have faced when accessing student finance from their local authority. It outlines that estrangement on the grounds of rejection of their sexuality can be a sensitive and complex matter, and the negative reaction of their parents initially led to a reticence to share personal information with statutory agencies. This study outlines that gathering evidence to prove estrangement and independence is a burden, and often a barrier to access to higher education. Those who accessed an advisor to support with the process of providing evidence of estrangement reported much better experiences and success with proving their situation (Malcolm, 2008).

This paper will update and build on this evidence. It will consider a larger, representative sample of estranged young people studying across the nations of the United Kingdom and include young people who are estranged due to other types of family difficulties.

\section{The process of proving family estrangement}


This paper will discuss the process of proving family estrangement for the purposes of accessing statutory finance in England and Wales. Student Loans Company Ltd consider that a young person is estranged if they have ceased communicative contact with their living biological or adoptive parents, normally for the period of one year. This estrangement should be irreconcilable (SLC, 2019). At the time of research, the process to prove this involves a student sending in letter(s) of evidence from a trusted third-party professional who can verify that their family estrangement has persisted, normally for a year, prior to the start of their course and that is irreconcilable. They are subsequently expected to prove this situation has not changed, with a further letter each year that they apply for finance. Decisions are made on a case-by-case basis by a team of experienced senior assessors (SLC, 2019) As such, this paper does not wish to dissect the process and its operational merits, rather explore how this process impacts estranged young people and their success in higher education.

\section{Research Question}

The research question this study addressed was: How did proving family estrangement to SLC impact the lives of UK students?

\section{Methodology}

This paper uses the data of 564 estranged independent students, who responded to an anonymous online survey facilitated by the Student Loans Company Ltd in June 2015. Student Loans Company Ltd controlled the sampling process, and elicited a sample of 5,000 students from an eligible pool of 8,116 students held on their database, who had been defined as 'irreconcilably estranged' from their living biological or adoptive parents for one year prior to the commencement of their studies. This status had been verified in the process of applying for finance from Student Finance England, Wales or Northern Ireland.

The sample of 5,000 matched the demographic profile of the overall group and was representative of their characteristics in age, gender, domicile and status of study. The questionnaire was open for two weeks and attracted responses from 564 students, representing an $11 \%$ response rate. 
European Union and European Economic Area nationals were excluded to focus the study on home students, as were participants who did not give an email address and could not receive the online participation link. Young people resident in Scotland do not interact with Student Loans Company Ltd to attain finance, and therefore it was not possible to access their data and include them in this research. However, a number of young people who accessed finance through Student Loans Company Ltd use this to study at Scottish universities and colleges. Therefore this study remains relevant to the higher education sector in Scotland.

The demographic profile of the eligible pool, sample and respondents is shown in Table 1 (see page 19 for table). Ethnicity was not part of the sampling procedure as such information is not volunteered by all students when applying for finance with SFE, SFW or SFNI. However, 31\% of the 564 respondents who took part in the study stated they were from non-white ethnic minority groups.

An online questionnaire was developed, comprising of 29 questions, which focused on access to finance, accommodation and the support offered both from the Student Loans Company Ltd and their university or college. The survey included both quantitative and open format questions, allowing students the opportunity to communicate the depth of their experiences and contextualise selected quantitative questions. The format of an anonymous survey and the potential questions were piloted using a steering committee of estranged young people studying in two English universities. This facilitated a tailoring of the language, ensuring it was not judgmental in tone and clear in wording and structure.

Ethical approval was gained from Dept. for Business, Innovation and Skills in advance of data collection and support was offered to any students who felt distressed by taking part in the survey. There was prominent signposting to charities with specialist skills in working with family estrangement, and a list of trained student support contacts at UK higher education institutions.

The online format was chosen to enable students who might feel ashamed or embarrassed by their family situation to come forward and take part anonymously. By using this method, it allowed students who might not otherwise have come forward, for fear of judgement, to retain anonymity and complete the survey in their own time and in an environment of their choosing.

564 students answered a multiple-choice question relating to how easy or difficult they found the process of accessing financial support from SLC. 562 students (96\% of the sample) expanded on their reasons as to why accessing financial support, as an estranged student, was difficult or easy. 
The qualitative data produced was analysed in accordance with the principles of thematic analysis (Braun \& Clarke, 2006). The process entailed the first author becoming familiar with the responses. Following familiarisation with the data, the second stage involved the generation of initial codes that closely resembled the respondents' own words. The first author did not use theory to inform, analyse or frame the answers. In the third stage, the codes were then collated into potential themes, whereby overlapping codes were merged. The themes were then reviewed by a senior researcher to ensure that they reflected the entire data set and the themes were defined and named. During the final stage of thematic analysis, extracts were selected and analysed in relation to the research question. The results below are grouped according to these themes and quotations from the participants are provided

\section{Findings and Discussion}

The study did not ask students directly for the reasons behind their estrangement. However, students volunteered the reasons throughout the data. These reasons included: undisclosed abuse in the family; issues with new step-parents after divorce and re-marriage; generational clashes of values and beliefs with immigrant family members; and differences in personality and values. The lack of involvement of local authorities meant that students reported having informal kinship care arrangements, commonly with a grandparent, or were living in homeless shelters run by third-sector organisations.

The vast majority of students in this study described the process of proving their family estrangement for SLC as being difficult or very difficult $(n=359)$. The process of evidencing this estrangement provided them with multiple and complex challenges, which are described below.

\section{Difficulties in Providing A Reference}

Most of the students found the process of obtaining evidence of their estrangement from a third-party professional to be the key to their difficulties. These students did not have a professional to call on as a reference and the expectations of the process meant they had to seek a professional and disclose their family estrangement to them.

Students had often passively concealed information about their family estrangement, as they had not been put in a situation where they would have needed to inform a professional. This 
makes sense in the context that the majority of students in this study had not had contact with local authorities or care services and had either removed themselves from their families or been in informal kinship care arrangements.

"I was asked to provide evidence of my estrangement from a doctor or professional person. However, I have always just got on with my life without complaining about the situation so nobody around me was aware of my estrangement."

Some students had actively concealed or hidden their situation. This process posed problems for these students, who felt like they were forced to disclose their situation to professionals even if they wanted it to remain private. The reticence to disclose information and purposefully conceal it builds on claims in the literature that people who are estranged from family experience stigma when talking to others (Agllias, 2017; Scharp, 2016; Malcolm, 2008). The sense of shame could be noticed when discussing the process:

"Do you not see that asking someone who was homeless and who doesn't have a family to make sure I tell other people of my sad little story is a little degrading? I don't want to tell people. I came to university to escape that life."

A minority of students in this category led transient lives, moving frequently between people and organisations that would house them. This led to a loss of contacts with people who may have known about their situation and very short-term relationships with key professionals in their locality. This had an impact on their ability to find a reference:

"Finding evidence to support my estrangement was very difficult as I have moved around a lot and changed teachers and doctors numerous times, so finding someone to vouch for my situation was tricky."

Building on this theme, students were expected to provide evidence of continued family estrangement to SLC each academic year. As a consequence, they struggled to find repeated references from those who had moved to new jobs, or professionals who had moved abroad. This left some students who had been classified as independent for one or two years of study struggling to retain independent status into their second 
or third year, despite having not reconciled or been in contact with their estranged parent(s).

\title{
Consequences on health and choices around family estrangement.
}

As a consequence of these difficulties, the majority of students reported high levels of stress and anxiety in the process. This was extreme enough in some cases to lead students into ending their studies, which builds on the literature around why estranged students may drop out (Bland, 2018). Others found it easier to reconcile with family than continue to prove independent status.
"I was constantly rejected, which caused me to go through anxiety attacks regularly - something I've never experienced before. I considered dropping out of university because I couldn't afford to go back without extra help. On top of dealing with this I had the additional family issues going on in the background. The process of gaining independent status was very stressful."

Students felt they were reminded of past trauma each time they supplied proof of their estrangement to SLC on an annual basis. This was compounded by the insecurity around whether they would have sufficient finance for the next academic year.

\author{
"I had to apply twice before my \\ psychologist and doctor wrote letters to \\ explain my circumstances. Once this was \\ done, I was awarded with support. \\ However, my mental health had \\ deteriorated with the stress, therefore I \\ suspended my studies and now have to \\ return the aid I received."
}

For estranged students the stress and emotional health challenges connected to evidencing family estrangement for statutory finance can impact decision making around suspension or withdrawal. This builds on the literature with the same cohort of estranged students, which links access to accommodation to poverty, and poverty as a key reason for estranged student withdrawal or suspension (Bland, 2018).

The students understood the rationale for asking for evidence of their family breakdown and appreciated the capacity for 
fraudulent applications. However, the tight guidelines on who could act as a reference frustrated a number of students as they gave them the impression they were not trusted.

"When attempting to access finance I felt like I was treated as someone who was lying about my estrangement with my parents. I understand that there is a need to prove that the estrangement has occurred but often when inquiring the response I received was apathetic and distrusting."

In a small number of cases, estranged young people felt it easier to reconcile with their parent than to prove their independence. This had an impact on their mental health:

"Obtaining the necessary evidence has been incredibly stressful and confusing (especially given that my situation is a little complicated), and in my foundation year this meant that I gave up trying and had to have contact with my mother, which had a serious impact on my mental health, which in turn impacted my ability to study."

These findings fall in alignment with NUS's prior research with estranged LGBT+ students, who also gave accounts of re-establishing contact with their parents to finance studies or evidence their estrangement. It also supports findings in the same study which indicated that estranged young people felt distrusted by those who administered their statutory student support (Malcolm, 2008).

\section{Consequences on personal finances and the student experience}

For the majority of estranged students who found it difficult to access statutory finance, the outcome of the process was not only stress and anxiety but also poverty and debt. Students reported delays in satisfying the criteria for independent status, which were not resolved as the academic term started. This led to delays in the receipt of payments that were necessary for them to take part in student life:

"When starting the course it took a while for my finances to come through, I didn't have any money for 3 months and couldn't get help from 
anyone. I struggled to stay on the course."

As a consequence, students questioned whether university life was for them. The literature on student persistence indicates that students who feel there is a prospect of academic success and personal career betterment are more likely to succeed in higher education (Thomas, 2012). It was clear from answers that the lack of payments inhibited the necessary focus on their studies if delays occurred in the second or final years of study.

"It took over 2 terms to actually get any money. I lived off no money for this period, used all my savings and borrowed a load of money off a friend."

This study also supports previous studies that claim estranged students are inclined to rely on peer networks for support (Simon, 2008, Bland 2018). This shows that peer networks supported them not only with accommodation difficulties, but also financial support. However, whilst some students leaned heavily on friends, the poverty and lack of finance did present students with challenges around their peer group. Some students felt the delays in their finance held them back from integrating fully:

"It is difficult because you cannot do the same things that all your friends are doing at university as you have to budget knowing that you can't afford the same luxuries."

Students entertained a consistent uncertainty around whether they would be able to afford to continue their studies and if it was worthwhile. For some students this consideration came after successfully completing years of study:

"My finance was delayed consequently making me so far behind in my final year that I decided to drop out because of the pressure and stress!"

Previous research with this group shows that estranged young people already struggle to meet their living costs when in receipt of the full SLC loan or grant as an independent student (Bland, 2018). This has been attributed to students stretching their finance over the summer period, which is a pressure 
period for those who have no family network to supply housing or financial support (Bland, 2018). This evidence shows that estranged young people in higher education have acute financial struggles in the first months of the academic year, whilst they are proving their independent status and dealing with potential delays to receiving finance. This can be true not only for new starters but for students at all stages of study.

This supports Robinson's (2018) claims that family breakdown may drastically alter the life course of children and young people, as young people may give up on higher education as a result of struggling to access statutory finance independently. It also builds on Taylor's (2019) suggestion that proving family estrangement can be challenging for students in Scotland. This study confirms that this is the case for those students who have not told professionals about their family situation across the UK.

\section{The importance of support}

The discussion to this point has considered the large numbers of students who found the process of accessing statutory finance difficult. Yet a small minority of estranged students did describe the process as easy $(n=88)$. These students consistently spoke of having access to, and the support of, a professional who knew of their family circumstances. These professionals assisted them with their application, and in most cases, provided a reference to verify their estrangement. Those who had been given a support worker from the local authority could rely on them for support, as could students with good relationships with teachers and sixth form tutors in schools.

"The initial process was fairly complicated, but when in touch with professionals who knew about my circumstances, e.g. sixth form tutor, I was able to compile the evidence necessary to apply for finance."

Overall, the whole sample showed that only a third of students had accessed support from their university in the areas of finance, accommodation or mental health. Female students were more likely to seek support, and those attending 'Russell Group' universities (a group of high calibre research-focussed UK universities) were more likely to do so. A further third of the sample did not know that support was available at their 
institution and a third did not feel comfortable accessing support around the issue.

Yet support at institutional level was seen as fundamental for some respondents when it came to accessing finance, and was frequently mentioned by students who had found the process easy. For many, this type of support was the only support they had been able to access:

"It wasn't until I was at university that I managed to receive the financial support I needed from SF, and that was through a tutor helping me get hold of the right evidence that I needed."

However, accessing of institutional support was not the only factor that influenced the ease or difficulty that students experienced in evidencing their estrangement. For example, some students who found this process to be easy, talked about how they felt at ease revealing personal family information to their tutors.

\section{Conclusion and Recommendations}

The findings of this study show that the process of proving family estrangement is complex and emotionally tumultuous for the majority of estranged young people who access higher education. The process of starting higher education may present young people with the aspiration to move beyond their difficult family life, but the process of gaining finance as an independent student binds them to their family dysfunction on an annual basis.

Although students are required to gain references from professionals to prove they are estranged from family, students rarely have organic relationships with such people. Estranged young people often feel shame around revealing their family estrangement, making it difficult to approach a professional. On the whole, these students are young people who have had little interactions with the care system or local authorities, which reduces further their chances of knowing a professional who understands their struggles. High job turnover in the caring and teaching professions and the transient lives of estranged young people exacerbated this requirement, and young people often lost touch with those who might may have acted as a sponsor. 
In this process, proving family estrangement was more straightforward for those who have a strong relationship with a third-party professional such as a teacher, university professional, social worker or medical professional who knew and understood their circumstances. However, awareness around the support available in university around this process was low.

The stress of finding a reference, and the yearly uncertainty around gaining maximum loan or grant as an independent student all posed risk factors to persistence. Poverty and mental health difficulties result from long delays in the evidencing process and the acquiring of finance. These consequences are particularly acute in the first months of the academic year.

Proving family estrangement where local authorities have not been involved is a complex area of social policy. Government departments are compelled to prevent fraudulent applications and abuses to the system and therefore must ask for verification beyond the testimony of the student. However, students in this position are owed a more straightforward, person-centred process to access statutory finance, which takes account of the emotive nature of family estrangement and disownment. At its heart, it should understand that not all students have disclosed their family breakdown to professionals. The burden of searching for proof of estrangement should be taken away from the student, and given to professionals in the field of family or social work, who could work compassionately with a student to understand and evidence the family breakdown, employing more than just a blunt referencing system. The requirement to provide evidence of family estrangement yearly should not be mandatory for all students and more discretion should be used in asking for repeated proof. The system would then become more robust in terms of fraud prevention, and would reduce risks to mental health and wellbeing for vulnerable students in all stages of the student life cycle. Wherever possible, a student's word should be believed. This is particularly important for survivors of familial abuse, who may be disclosing this information for the first time. Although the statutory financing process is administrational, it is also a vital juncture to bring into support some of the most vulnerable young people in our society. Thus, joined up and crossdepartmental working is essential.

To involve social work professionals in the process would also allow estranged young people to be more visible and better targeted and recognised for support in UK universities.

Separate from the recommendations above, it is clear that 
universities need to offer clearer and better sign-posted support to young people who may experience delays in accessing the appropriate level of student finance as an estranged student.

These recommendations would depend on investment from each national government and their higher education bodies in better understanding and supporting estranged young people into their early adult lives.

Although parental income may be used to 'means test' student entitlements, there is no legal statute that obligates a parental household to pay the expected contribution following this assessment (Lewis 2017). This leaves already means-tested young people vulnerable when family relationships sour, new families form post divorce, familial abuse is uncovered, when a young person starts a relationship outside of their religion, 'comes out' as LGBT+ or is pressured into marriage. It puts young adults at the mercy of strong family relationships, which cannot be guaranteed or made obligatory.

This study suggests that the means-testing process disadvantages independent and estranged young people when they are handed the burden to prove a negative family relationship that social services were not aware of or did not act upon. When considered in parallel to the stigma and secrecy around family estrangement, a type of hidden disadvantage is formed for estranged young people. This can have a huge bearing on their equitable experience in higher education and beyond.

For a truly equitable process to emerge, all young people should be given access to equal and sufficient amounts of maintenance support from government without means-testing the parental household. Although this would demand serious investment from government, it would allow for true equality in access, which is a position widely supported by governments of all colours in the four nations of the UK.

This study samples from students who successfully completed the process of proving their family estrangement, and managed to find an adequate referee to gain independent status with SLC. It is unknown how many UK estranged students gave up on the process of accessing higher education because they were not able to meet the requirements of gaining independent status. Further work should be carried out to understand their experience and subsequent trajectories in higher education and beyond.

\section{Bibliography}


Agllias, K. (2011). No Longer on Speaking Terms: The Losses Associated with Family Estrangement at the End of Life. Families in Society: The Journal of Contemporary Social Services, 92(1), 107-113. https://doi.org/10.1606/1044-3894.4055

Agllias, K. (2013). The Gendered Experience of Family Estrangement in Later Life. Affilia, 28(3), 309-321. https://doi.org/10.1177/0886109913495727

Agllias, K. (2017). Missing Family: The Adult Child's Experience of Parental Estrangement. Journal of Social Work Practice, pp. 1-15. https://doi.org/10.1080/02650533.2017.1326471

Ali, A. (2016). Students Struggling To Fill 3000 Finance gap a year as living costs soar, survey finds. The Independent. Retrieved from https://www.independent.co.uk/student/student-life/finances/studentsstruggling-to-fill-3000-finance-gap-a-year-as-living-costs-soar-surveyfinds-a7146206.html

Blake, L. (2015). Hidden Voices: Family Estrangement in Adulthood. Retrieved from http://standalone.org.uk/wpcontent/uploads/2015/12/HiddenVoices.FinalReport.pdf

Blake, L. (2017). Parents and Children who are Estranged in Adulthood. A Review and Discussion of the Literature.

Bland, B. (2018, August 2). Why is the government halting loan payments to vulnerable students? The Guardian. Retrieved from https://www.theguardian.com/higher-education-network/2018/aug/02/whyis-the-government-halting-loan-payments-to-vulnerable-students

Bland, R., \& Shaw, J. (2015). New Starts: The Challenges of Higher Education without the Support of A Family Network. London. Retrieved from http://standalone.org.uk/wpcontent/uploads/2013/08/StandAloneUNITEfoundation.pdf

Braun, V., \& Clarke, V. (2006). Using Thematic Analysis in Psychology. Qualitative Research in Psychology, 3(May 2015), 77-101. https://doi.org/10.1191/1478088706qp063oa

Cotton, D. R. E., Nash, P., \& Kneale, P. E. (2014). The Experience of Care leavers in UK Higher Education. Widening Participation \& Lifelong Learning, 16(3), 5-21. Retrieved from http://10.0.21.80/WPLL.16.3.5\%5Cnhttps://ezp.lib.unimelb.edu.au/login?ur l=https://search.ebscohost.com/login.aspx?direct=true \&db=ehh\&AN=9931 $5219 \&$ site $=$ eds-live \&scope $=$ site

Ellet, P. (2017). Quick guide to student finance if you're from England. Retrieved from https://university.which.co.uk/advice/student-finance/quickguide-to-fees-and-finance-if-youre-studying-in-england

Gov.uk. (2017). Student Finance: How to Apply. Retrieved from https://www.gov.uk/apply-for-student-finance/household-income

Jackson, S. (2006). By Degrees: Going to University From Care.

OFFA (Office For Fair Access). (2016). Topic Briefing: Estranged Students. Bristol. Retrieved from https://www .offa.org.uk/universities-andcolleges/guidance/topic-briefings/topic-briefing-estranged-students/

Robinson, B R. (2018) Conditional Families and Lesbian, Gay, Bisexual, Transgender, and Queer Youth Homelessness: Gender, Sexuality, Family Instability, and Rejection, Journal of Marriage and Family 80 (April 2018): 383-396 383 DOI:10.1111/jomf.12466

Scharp, K.M \& McLaren, R. M. (2017). Uncertainty Issues and Management in Adult Children's of their Estrangement with their Parents. Journal of Social and Personal Relationships. 
Scharp, K. M. (2016). Parent-Child Estrangement: Conditions for Disclosure and Perceived Social Network Member Reactions. Family Relations, 65(5), 688-700. https://doi.org/10.1111/fare.12219

Scharp, K. M., Thomas, L. J., \& Paxman, C. G. (2015). "It Was the Straw that Broke the Camel's Back": Exploring the Distancing Processes Communicatively Constructed in Parent-Child Estrangement Backstories. Journal of Family Communication, 15(4), 330-348. https://doi.org/10.1080/15267431.2015.1076422

Simon, A. (2008). Early access and use of housing: Care leavers and other young people in difficulty. Child and Family Social Work, 13(1), 91-100. https://doi.org/10.1111/j.1365-2206.2007.00524.X

SLC. (2019). Estranged Students. Retrieved April 24, 2019, from http://www.sfengland.slc.co.uk/estrangement.aspx

Stupart, Y. (2018). How Stress Affects College Students. Retrieved April 13, 2018, from https://owlcation.com/academia/College-Life-The-Effectsof-Stress-on-Academic-Performance

Taylor Yvette. (2019). Estranged Students in Higher and Further Education. Glasgow.

Thomas, L. (2012). What works? Building Student Engagement and Belonging in Higher Education At A Time Of Change. Retrieved from https://www.heacademy.ac.uk/system/files/what_works_final_report_0.pdf Union of Students, N. (2008). Evaluating Estrangement.

Wheel, S. (2018, August 2). Student Loans Company "spied on vulnerable students" social media'. The Guardian. Retrieved from https://www .theguardian.com/education/2018/aug/02/student-loanscompany-spied-on-vulnerable-students-social-media

https://www.practitioners.slc.co.uk/products/full-time-undergraduateeducation/full-time-maintenance-loan/whats-available/ 
Table 1: The demographic profile of eligible pool, sample and respondents.

\begin{tabular}{|l|r|r|r|}
\hline & $\begin{array}{r}\text { Pool } \\
(\mathbf{8 1 1 6 )}\end{array}$ & $\begin{array}{c}\text { Sample } \\
(\mathbf{5 0 0 0})\end{array}$ & $\begin{array}{c}\text { Respondents } \\
\text { (564) }\end{array}$ \\
\hline SFE & $93 \%$ & $93 \%$ & $94 \%$ \\
\hline SFNI & $3 \%$ & $3 \%$ & $2 \%$ \\
\hline SFW & $5 \%$ & $5 \%$ & $4 \%$ \\
\hline Age & & & $2 \%$ \\
\hline 18 & $2 \%$ & $2 \%$ & $10 \%$ \\
\hline 19 & $11 \%$ & $11 \%$ & $22 \%$ \\
\hline 20 & $19 \%$ & $19 \%$ & $26 \%$ \\
\hline 21 & $23 \%$ & $23 \%$ & $18 \%$ \\
\hline 22 & $18 \%$ & $18 \%$ & $11 \%$ \\
\hline 23 & $13 \%$ & $13 \%$ & $7 \%$ \\
\hline 24 & $9 \%$ & $9 \%$ & \\
\hline 25 & $5 \%$ & $5 \%$ & $72 \%$ \\
\hline Sex & & & $28 \%$ \\
\hline F & $60 \%$ & $60 \%$ & \\
\hline M & $40 \%$ & $40 \%$ & $3 \%$ \\
\hline $\begin{array}{l}\text { Status of } \\
\text { Study }\end{array}$ & & & \\
\hline Approved & $94 \%$ & $94 \%$ & \\
\hline Suspended & $2 \%$ & $2 \%$ & $3 \%$ \\
\hline Withdrawn & $4 \%$ & $4 \%$ & \\
\hline
\end{tabular}

